\title{
PENGARUH BIMBINGAN MANAJEMEN DIRI DALAM MENINGKATKAN KEDISIPLINAN BELAJAR SISWA
}

Titi Mirawati Asim

Konselor SMA, SMA Atirah Makassar

Email: titibayu@yahoo.com

\begin{abstract}
The study was helt in atirah I senior high school grade XI at Makassar city the purpose is to know (1) the process and results of implementation of self management guidance in improving learning discipline experimental group students of. (2) the level of learnig discipline to learn the experimental group before and after the self-management guidance services. (3) the level of learning discipline of the control group before and after teach by giving information about the desciplane. (4) whether there are differences between the application of self-management guidance and information services in improving the efficientcy of learn discipline. This research uses and experimental approach (True Experimental Designs) in the form of pretest-posttest control group design. This study used data collection techniques by questionnaires, observation and evaluation of the understanding. Data analysis using descriptive statistical analysis of Wilcoxon signed ranks test. The results of this study indicate (1) The process of experimentel was running well. (2) level of discipline studying students before the experimental group was given selfmanagement guidance services that are in the low category, while the level of discipline to learn the experimental group of students after being given self-management guidance services are in high category. (3) The level of discipline to learn the control group before and after teacing through information services remain at a low category, (4) there is a difference in learning discipline of experiental group student which giving self management guidance, and control groub students which giving information services.
\end{abstract}

Keywords: self-management guidance, students learn discipline

\begin{abstract}
ABSTRAK
Penelitian ini dilaksankan dikelas XI SMA Islam Atirah I Makassar dengan tujuan untuk mengetahui: (1) proses pelaksanan bimbingan manajemen diri dalam meningkatkan kedisiplinan belajar siswa. (2) tingkat kedisiplinan belajar kelompok eksperimen sebelum dan sesudah diberikan bimbingan manajemen diri. (3) tingkat kedisiplinan belajar kelompok kontrol sebelum dan sesudah diberikan layanan informasi cara belajar efisien. (4) apakah ada perbedaan antara penerapan bimbingan manajemen diri dan layanan informasi cara belajar efesien dalam meningkatkan kedisiplinan belajar. Penelitian ini menggunakan pendekatan eksperimen (True Experimental Designs) dalam bentuk PretestPosttest Control Group Design. Penelitian ini menggunakan teknik pengumpulan data melalui angket, observasi dan evaluasi pemahaman. Analisis data menggunakan analisis statistic deskriptif wilcoxon signed ranks test. Hasil penelitian ini menunjukkan (1) proses pelaksanaan bimbingan manajemen diri berjalan dengan baik. (2) Gambaran tingkat kedisiplinan belajar kelompok eksperimen siswa sebelum diberikan layanan bimbingan manajemen diri berada pada kategori rendah, sedangkan tingkat kedisiplinan belajar kelompok eksperimen siswa setelah diberikan layanan bimbingan manajemen diri berada pada kategori tinggi. (3) Gambaran tingkat kedisiplinan belajar kelompok kontrol sebelum dan sesudah diberikan layanan informasi belajar tetap berada pada kategori rendah, (4) ada perbedaan antara Bimbingan manajemen diri dengan layanan informasi cara belajar efisien dalam meningkatkan kedisiplinan belajar siswa kelas XI SMA Islam Athirah 1 Makassar
\end{abstract}

Kata Kunci : bimbingan manajemen diri, kedisiplinan belajar siswa 


\section{PENDAHULUAN}

Sekolah merupakan sarana memperoleh berbagai ilmu pengetahuan dan keterampilan. Berbagai jenjang pendidikan yang terdapat di Indonesia sifatnya formal yang diistilahkan dengan sistem pendidikan persekolahan mulai dari jenjang sekolah dasar hingga pendidikan tinggi. Tujuan keberadaan pendidikan persekolahan dimaksudkan untuk mencapai tujuan pendidikan nasional guna meningkatkan kualitas manusia Indonesia, sebagaimana tercantum dalam Undang-undang Republik Indonesia Nomor 20 tahun 2003 tentang Sistem Pendidikan Nasional, pasal 3 (2003: 4) yaitu: yang menyatakan bahwa: untuk berkembangnya potensi siswa agar menjadi manusia yang beriman dan bertakwa kepada Tuhan Yang Maha Esa, berakhlak mulia, sehat, berilmu, cakap, kreatif, mandiri dan menjadi warga negara yang demokratis serta bertanggungjawab.

Dalam mewujudkan tujuan pendidikan secara maksimal, maka pemerintah mengupayakan menciptakan suatu wadah yakni sekolah yang merupakan salah satu tempat berlangsungnya kegiatan proses belajar mengajar. Berhasil tidaknya pencapaian tujuan pendidikan hanya bergantung pada bagaimana proses belajar yang dialami murid sebagai siswa di sekolah. Agar proses belajar mengajar berjalan dengan lancar, maka seluruh siswa harus mematuhi tata tertib sekolah dengan penuh rasa disiplin yang tinggi. Menurut Soegeng Prijodarminto (Bahri, 2012) disiplin adalah suatu kondisi yang tercipta dan terbentuk dari serangkaian perilaku yang menunjukkan nilainilai ketaatan, kepatuhan, kesetiaan, atau keterkaitan terhadap sesuatu peraturan tata tertib.

Disiplin dapat tumbuh dan dibina melalui latihan, pendidikan atau penanaman kebiasaan yang harus dimulai sejak dalam lingkungan keluarga, mulai pada masa kanakkanak dan terus berkembang sehingga perilakunya menjadi kepribadian disiplin. Sebagaimana dikemukakan oleh Soegeng Prjodarminto (Bahri, 2012) bahwa "dengan disiplin yang muncul karena kesadaran diri, siswa berhasil dalam belajarnya".

Belajar dengan disiplin yang terarah dapat menghindarkan diri dari rasa malas dan menimbulkan kegairahan siswa dalam belajar, yang pada akhirnya akan dapat meningkatkan daya kemampuan belajar siswa. Disiplin adalah kunci sukses dan keberhasilan. Dengan disiplin seseorang menjadi yakin bahwa disiplin akan membawa manfaat yang dibuktikan dengan tindakannya. Setelah berprilaku disiplin, seseorang akan dapat merasakan bahwa disiplin itu pahit tetapi buahnya manis. Disiplin memberikan manfaat yang besar dalam diri seseorang. Sepintas bila kita mendengar kata disiplin maka yang selalu terbayang usaha untuk menyekat, mengawal dan menahan. Padahal tidak demikian, sebab disiplin bermakna melatih, mendidik dan mengatur atau hidup teratur. Artinya kata disiplin itu tidak terkandung makna sekatan, tetapi juga latihan. Untuk itulah kedisiplinan sangat diperlukan dalam usaha meningkatkan suatu kehidupan yang teratur dan meningkatkan prestasi dalam belajar karena sifatnya yang mengatur dan mendidik. Dari kebanyakan orang-orang sukses rasanya tidak ada diantara mereka yang tidak berdisiplin, kedisiplinan yang tertanam dalam setiap kegiatan mereka yang membawa kesuksesan.

Sikap disiplin yang baik adalah terciptanya aktivitas yang mampu mengatur diri kepada terciptanya pribadi dan potensi sosail berdasar pengalaman-pengalamannya sendiri. Sikap disiplin harus mampu dimiliki oleh setiap siswa dalam hal meningkatkan serta mengembangkan kemampuan yang dimilikinya. Sikap tersebut dapat terlatih dan dilatih. Dilatih yaitu siswa sendiri yang berusaha untuk meningkatkan kedisiplinannya, apakah dengan mencari literatur atau bertanya kepada orang lain. Sedangkan dilatih yaitu meminta bantuan kepada seseorang yang berkompeten dalam bidangnya untuk dibimbing dalam meningkatkan sikap disiplin.

Pada kenyataannya di SMA Islam Athirah 1 Makassar menunjukkan bahwa ada 56 siswa kelas XI yang selalu keluar masuk dan kalau ditegur tidak mau mendengar, tidak mengerjakan tugas dengan baik dan mengumpulkannya selalu telat, jika ulangan selalu mengandalkan teman(menyontek), anak tersebut hanya lebih fokus pada handpone, selalu ingin keluar kelas, sering tertidur di kelas dan menggunakan pakai seragam yang tidak lengkap. Informasi ini terungkap pada saat pertemuan 
dengan dewan guru tentang kondisi siswa. Guru Mata pelajaran sudah berulang kali mengingatkan kepada siswa untuk mengumpulkan tugas dengan tepat waktu, tidak menggunakan handpone pada saat belajar, tidak bercerita saat guru menjelaskan, hanya boleh keluar sendiri tidak perlu ditemani oleh teman, jika ulangan harus andalkan diri sendiri dan tidak tidur di kelas. Selain itu, Guru Bimbingan dan Konseling sudah pernah mengkonseling kelompok siswa. Namun, usaha tersebut belum memberikan hasil yang optimal. Dari perilaku dan dari alasan yang diberikan siswa yang selalu menunjukkan bahwa bukan orang lain yang membuatnya berperilaku seperti itu, tertapi karena dia tidak mampu untuk mengatur diri sendiri dan tidak percaya pada kemampuannya sendiri. Oleh karena itu, untuk mengatasi masalah tersebut, penulis memilih salah satu alternatif pemecahan masalah yaitu dengan memberikan dan menerapkan bimbingan manajemen diri (self-management) kepada siswa. Manajemen diri diharapkan agar siswa mampu merencanakan, mengatur dan mengelola serta mengontrol dirinya sendiri dalam melakukan sesuatu kegiatan terutama dalam belajar sehingga siswa betul-betul dapat memanfaatkan waktunya seefisien dan seefektif mungkin.

Menurut Cormier \& Cormier (1985: 520) menekankan bahwa self management bukanlah suatu pendekatan yang sepenuhnya deterministik yang menyingkirkan potensi konseli untuk membuat pilihan atau keputusan. Selanjutnya dikatakan bahwa dalam proses belajar untuk menghasilkan perilaku, aspek kognitif juga memiliki peranan penting, terutama dalam mempertimbangkan berbagai tindakan yang hendak dilakukan. Dari dasar itulah maka penulis berasumsi bahwa kedisiplinan siswa dalam belajar dapat ditingkatkan dengan melalui manajemen diri.

Pendekatan terbaru dari pandangan behavioral dalam belajar adalah manajemen diri, yaitu membantu siswa agar mampu mengontrol kegiatan belajarnya. Peran siswa dalam kegiatan belajarnya merupakan perhatian utama dari para psikologi dan para pendidik saat ini. Pengertian manajemen diri berangkat pada satu ide penting yaitu tanggung jawab dan kemampuan belajar diri siswa. Schunk (Uno, 2006) menyatakan bahwa "tidak ada orang yang mampu untuk belajar demi kepentingan orang lain melainkan kepentingan untuk dirinya sendiri”.
Menurut Desmita (2007: 180) mengemukakan "Bimbingan Manajemen diri adalah struktur yang membantu anak mengorganisasi dan memahami tentang siapa dirinya, yang didasarkan atas pandangan orang lain, pengalaman-pengalamannya sendiri, dan atas dasar penggolongan budaya.

Cormier (2009: 524) mengemukakan latihan manajemen diri menjadi 3 bagian yaitu 1) pemantauan diri (self-monitoring), 2) pengendalian ransangan (stimulus-control), 3) penghargaan diri sendiri (self-reward).

Damayanti (Arsanti, 2015) disiplin belajar adalah suatu sikap, tingkah laku dan perbuatan siswa untuk melakukan aktivitas belajar yang sesuai dengan keputusan-keputusan, peraturan-peraturan, dan norma-norma yang telah ditetapkan bersama, baik persetujuan tertulis maupun tidak tertulis antara siswa dengan guru disekolah maupun dengan orang tua di rumah. Sedangkan menurut Wahyono (Rasmidah, 2015) disiplin belajar adalah predis posisi12 (kecenderungan) suatu sikap mental untuk mematuhi aturan, tata tertib, dan sekaligus mengendalikan diri, menyesuaikan diri terhadap aturan-aturan yang berasal dari luar sekalipun yang mengekang dan menunjukkan kesadaran akan tanggung jawab terhadap tugas dan kewajiban

Tujuan penelitian ini adalah untuk (1) mengetahui proses eksperimen, (2) disiplin belajar siswa kelompok eksperimen sebelum dan sesudah diberi perlakuan, (3) disiplin belajar siswa kelompok kontrol sebelum dan sesudah diberikan informasi cara belajar efisien sedangkan hipotesis penelitian ini adalah terdapat perbedaan yang signifikan antara disiplin belajar siswa kelompok eksperimen dan kelompok kontrol.

\section{METODOLOGI PENELITIAN}

\section{Jenis dan Disain Penelitian}

Penelitian ini merupakan jenis penelitian kuantitatif yang menguji secara langsung hipotesis tentang perbedaan tingkat kedisplinan belajar siswa antara kelompok eksperimen sebelum dan sesudah diberikan bimmbingan manajemen diri dengan kelompok kontrol sebelum dan sesudah diberikan layanan informasi cara belajar efisien. Adapun Disain eksperimen yang digunakan adalah Pretest- 
Posttest Control Group Design yang dapat digambarkan sebagai berikut:

\begin{tabular}{llll}
\hline Kelompok & $\begin{array}{l}\text { Pre } \\
\text { test }\end{array}$ & Perlakuan & $\begin{array}{l}\text { Post } \\
\text { test }\end{array}$ \\
\hline $\begin{array}{l}\text { Eksperimen } \\
\text { (E) }\end{array}$ & O1 & $\mathrm{X} 1$ & $\mathrm{O} 3$ \\
\hline Kontrol (K) & $\mathrm{O} 2$ & $\mathrm{X} 2$ & $\mathrm{O} 4$
\end{tabular}

Sumber : Sugiyono (2011: 112)

Dimana:

$\mathrm{E}=$ Kelompok eksperimen

$\mathrm{K}=$ Kelompok kontrol

$\mathrm{O} 1=$ Pre test kelompok eksperimen

$\mathrm{O} 2=$ Pre test kelompok kontrol

$\mathrm{X} 1=$ Treatmen atau perlakuan (manajemen diri)

$\mathrm{X} 2=$ Treatmen atau perlakuan (Layanan informasi belajar efisien diberikan oleh Konselor sekolah)

$\mathrm{O} 3$ = Post test kelompok eksperimen

O4 = Post test kelompok kontrol

Variable peneliotian ini terdiri terdiri dua variabel yaitu "Bimbingan Manajemen Diri“ sebagai variabel bebas (independen) dan "Kedisiplinan belajar siswa" sebagai variabel terikat (dependent).

Guna memperoleh batasan tentang kedua variabel, maka perlu dibuat definisi operasional dari variabel tersebut, yaitu:

1. Bimbingan manajemen diri adalah pemberian bantuan kepada siswa yang mengalami tingkat kedisiplinan belajar rendah yang diharapkan mampu mengelola pikiran, perilaku dan perasaan dalam diri sehingga kedisiplinan belajar siswa meningkat. Ada 3 teknik manajemen diri yang digunakan dalam penelitian ini yaitu. 1) pemantauan diri (selfmonitoring), 2) pengendalian ransangan (stimulus-control), dan 3) penghargaan diri sendiri (self-reward).

2. Kedisipinan siswa dalam belajar adalah kepatuhan siswa dalam mengikuti aturan tata tertib yang berlaku disekolah khususnya dalam proses belajar mengajar yaitu mengerjakan tugas dengan baik dan tepat waktu, memanfaatkan dengan baik waktu dalam kelas serta selalu menggunakan seragam lengkap yang sesuai aturan sekolah yang berlaku,

Populasi dan sampel penelitian didapatkan dari hasil pertemuan forum guru di
SMA Islam Athirah 1 Makassar. Forum tersebut membahas tentang kondisi dan perkembangan siswa. Informasi tentang kedisiplinan belajar siswa didapatkan dari info beberapa guru mata pelajaran. Populasi dalam penelitian ini sebanyak 56 siswa.

Teknik pengambilan sampel (teknik sampling) yang digunakan adalah simple random sampling yaitu cara pengambilan sampel dari anggota populasi dengan menggunakan acak tanpa memperhatikan strata (tingkatan) dalam anggota populasi tersebut. Umar (Dini:2011) menjelaskan bahwa untuk menentukan jumlah sampel dari populasi yang akan diteliti, digunakan metode Slovin dengan rumus sebagai berikut:

$$
\mathrm{n}=\frac{\mathrm{N}}{1+\mathrm{N}(\mathrm{e}) 2}
$$

$\mathrm{N}$ : jumlah populasi

$\mathrm{n}$ : jumlah sampel

e: kesalahan dalam mengambil sampel yang ditetapkan sebesar $10 \%$

Dalam penelitian ini sampel yang diambil secara acak sesuai dengan rumus sampel sebelumnya yaitu:

$$
\begin{aligned}
\mathrm{n} & =\frac{\mathrm{N}}{1+\mathrm{N}(\mathrm{e}) 2} \\
& =\frac{56}{1+56(0,1) 2} \\
& =\frac{56}{1+56(0,01)} \\
& =56
\end{aligned}
$$

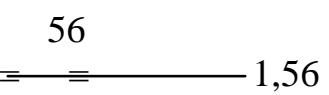

\section{$=35,89$ atau 36 (dibulatkan)}

Oleh karena itu jumlah sampel dalam penelitian ini adalah 36 siswa. Berikutnya adalah penentuan kelompok kontrol dengan kelompok eksperimen. Dalam penentuan kelompok eksperimen dan kontrol ini sesuai pendapat Bungin (2013) bahwa dapat dilakukan dengan cara membuat daftar unit populasi pada lembaran khusus lengkap dengan kode-kode setiap unit populasi, kemudian kode-kode tersebut ditulis dalam lembaran-lembaran kecil dan 
dilipat/digulung satu persatu, kemudian kita masukan kedalam suatu tempat (misalnya, Kaleng/box) dan dikocok. Setelah diundi ternyata 18 siswa kelompok eksperimen sedangkan kelompok kontrol juga 18 siswa.

Angket merupakan teknik pengumpulan data yang dilakukan dengan cara memberi seperangkat pernyataan tertulis kepada respon untuk dijawabnya. Angket ini diberikan kepada kelompok eksperimen dan kelompok kontrol untuk memperoleh gambaran tentang kedisiplinan belajar siswa, pada kelompok eksperimen sebelum dan sesudah diberikan bimbingan manajemen diri. Dan pada kelompok kontrol sebelum dan sesudah diberikan layanan informasi cara belajar efisien

Teknik observasi ini dilakukan untuk mengetahui keaktifan siswa dalam mengikuti kegiatan bimbingan manajemen diri pada kelompok eksperimen. Menurut Riduwan (2009: 76) observasi yaitu melakukan pengamatan secara langsung ke objek penelitian untuk melihat dari dekat. Adapun aspek-aspek yang diobservasi adalah umum dan pemahaman siswa tentang manajemen diri dengan cara memberi tanda silang (x) pada setiap aspek yang muncul. Pelaksanaan observasi dibantu oleh guru BK di sekolah.

Ada dua jenis instrumen yang digunakan dalam penelitian ini yaitu:

1. Bahan perlakuan berupa materi.bimbingan manajemen diri yang meliputi manajemen diri

(1) self monitoring, (b) stimulus control dan

(3) self reward. Pelaksanaaan bimbingan manajemen diri ini terbagi dalam tiga sesi pertemuan termasuk pretest dan posttest. (lihat lampiran 2 )

2. Instrumen pengumpulan data yang berupa angket kedisiplinan belajar terlebih dahulu divalidasi ahli dan selanjutnya diuji lapangan terbatas untuk mengetahui validasi dan realibilitasnya.

Tekbik analisis data menggunakan teknik analisis statistik deskriptif dimaksudkan untuk menganalisis data tingkat kedisiplinan belajar kelompok eksperimen sebelum dan sesudah perlakuan berupa teknik bimbingan manajemen diri dan kelompok kontrol sebelum dan sesudah diberi informasi belajar efisien.

Teknik observasi ini dilakukan untuk mengetahui keseriusan siswa dalam mengikuti kegiatan manajemen diri pada kelompok eksperimen dalam meningkatkan kedisiplinan belajar siswa.

Teknik evaluasi ini dilakukan untuk mengetahui seberapa baik pemahaman siswa terhadap bimbingan manajemen diri maka perlu dilakukan evaluasi disetiap akhir pertemuan.

Selain itu digunakan juga teknik analisis statistic inferensial. Analisis statistik inferensial dimaksudkan untuk menguji kebenaran hipotesis penelitian. Analisis dilakukan untuk mengetahui apakah ada pengaruh penerapan bimbingan manajemen diri dapat meningkatkan kedisiplinan belajar siswa kelas XI SMA Islam Athirah 1 Makassar dan apakah siswa yang memperoleh pelatihan manajemen diri disiplin dirinyaa lebih baik dari siswa yang tidak memperoleh pelatihan manajemen diri di SMA Islam Athirah 1 Makassar., dengan menggunakan uji wilcoxonnon parametric kemudian dianalisis dengan menggunakan SPSS 22,0.

\section{HASIL DAN PEMBAHASAN}

\section{Hasil}

\section{Proses eksperimen}

teknik observasi dilakukan untuk mencatat reaksi-reaksi dan partisipasi siswa selama mengikuti kegiatan bimbingan manajemen diri melalui pengamatan langsung terhadap subyek penelitian. Aspek-aspek yang diobservasi adalah memperhatikan penjelasan yang diberikan, mengajukan pertanyaan jika belum dipahami, mengungkapkan pendapat secara sukarela, posisi duduk selalu tegak dan penuh perhatian, mampu mengidentifiasi perilaku yang akan dimonitoring, aktif memberikan dukungan, aktif mengerjakan latihan, mampu mengenal perilaku yang membuatnya tidak displin dalam belajar, mampu menyusun strategi, dan mampu memberikan reward bagi diri sendiri dan orang lain.

\section{Hasil penguasaan materi}

Berdasarkan hasil evaluasi penguasaan materi menujukkan bahwa sampel penelitian mengalami peningkatan pemahaman dan mampu memahami materi bimbingan manajemen diri dengan baik.

\footnotetext{
Deskripsi Kedisiplinan Belajar Siswa Kelompok Eksperimen Sebelum dan Sesudah Diberikan Bimbingan Manajemen Diri
} 
Tingkat kedisiplinan belajar siswa di SMA Islam Athirah 1 Makassar untuk kelompok eksperimen saat pretest sebanyak 4 responden atau 22,22 persen berada pada kategori sangat rendah dan 14 responden atau 77,78 persen berada pada kategori rendah. Setelah diberikan perlakuan berupa bimbingan manajemen diri sebanyak 5 tahap, maka tingkat kedisiplinan siswa mengalami peningkatan, dimana sebanyak 12 responden atau 66,67 persen berada pada kategori tinggi dan 6 responden atau 33,33 persen yang berada pada kategori rendah yang berarti dominan responden berada pada kategori tinggi.

\section{Deskripsi Kedisiplinan Belajar Siswa Kelompok Kontrol Sebelum Dan Ses udah Diberikan Layanan Informasi Belajar Efisien}

Tingkat kedisiplinan belajar siswa pada kelompok kontrol saat pretest terdapat 16 responden atau 88,89 persen yang berada pada kategori rendah dan 2 responden atau 11,11 persen yang berada pada kategori sangat rendah berarti siswa cenderung tidak disiplin dalam belajar. sedangkan pada saat postest kondisi tersebut tidak menunjukkan perubahan yang berarti, dimana 16 responden atau 88,89 persen yang berada pada kategori rendah dan 2 responden atau 11,11 persen yang berada pada kategori sangat rendah, berarti kecenderungan ketidakdisiplinan belajar siswa pada siswa kelompok kontrol tidak mengalami perubahan.

\section{Uji Hipotesis}

Hasil uji hipotesis Asymp. Sig. (2-tailed) uji dua sisi adalah 1,000. Karena tingkat kedisiplinan belajar siswa adalah uji satu sisi, maka probabilitas menjadi 1.000/2 $=0,5$. Disini didapat probabilitas diatas $0,05(0,5>0,05)$. Maka H0 diterima dan hipotesis kerja (H1) dinyatakan ditolak. Artinya bimbingan manajemen diri lebih berpengaruh dalam meningkatkan kedisiplinan belajar kelompok eksperimen dibandingkan dengan kelompok kontrol yang hanya diberi layanan informasi cara belajar efisien.

\section{Pembahasan}

Berdasarkan data hasil observasi atas bantuan guru BK, menunjukkan bahwa seluruh siswa sangat hikmah dalam memperhatikan penjelasan materi yang disajikan, mengajukan pertanyataan dan mengemukakan pendapat dengan sukarela. Selain itu, seluruh siswa semangat dalam berusaha untuk mengubah perilakunya menjadi disiplin dalam belajar ditandai dengan kemampuan siswa dalam menjanjikan hadiah untuk dirinya sebagai salah satu motivasi keberhasilannya.

Berdasarkan hasil analisis pengua-saan materi bimbingan manajemen diri menujukkan bahwa setiap sesi pertemuan, siswa mampu memahami materi yang disajikan peneliti, mampu mengerjakan LK dan secara umum siswa mampu mengaplikasikan tiga teknik bimbingan manajemen diri walaupun masih ada beberapa siswa yang masih perlu bantuan peneliti. Selain itu, dalam hasil penguasaan materi ini pun mengungkap bahwa siswa merasa bahwa pemberian materi ini sangat bermanfaat bagi permasalahan yang diha-dapinya.

Kelompok eksperimen pada hasil prestest berada pada kategori rendah. Hal tersebut berarti bahwa siswa dengan sikap sering tidak mengerjakan tugas dengan baik dan tepat waktu, menyontek pekerjaan teman, kurang aktif dalam mengikuti pembelajara kurang kehadiran di dalam kelas saat PBM, berpakaian seragam yang tidak lengkap masih tergolong tinggi. Secara statistic dapat dibuktikan yaitu saat pretest sebanyak 4 responden atau 22,22 persen berada pada kategori sangat rendah dan 14 responden atau 77,78 persen berada pada kategori rendah.

Dari hasi penelitian ini menunjukkan perilaku siswa sudah berubah yaitu sisiwa sudah mau meminta izin ketika meninggal kelas, mengerjakan tugas dengan mandiri, mengumpulkan tugas sesuai dengan waktu yang telah ditentukan, rajin masuk ke sekolah dan intensitas keterlambatan datang ke sekolah sudah menurun, menggunakan pakaian yang sesuai dengan standar sekolah (memakai papan nama, memakai kaos kaki warna putih).

Berdasarkan hasil analisis statistik inferensial menunjukkan bahwa bimbingan manajemen diri berpengaruh dalam meningkatkan kedisiplinan belajar siswa daripada layanan informasi cara belajar efisien. Hasil uji hipotesis nihil (Ho) dinyatakan ditolak dan kensekuensinya hipotesis kerja (H1) diterima, maka dapat disimpulkan bahwa ada perbedaan antara bimbingan manajemen dengan layanan cara belajar efisien dalam meningkatkan 
kedisiplinan belajar siswa SMA Islam Athirah 1 Makassar yaitu Bimbingan manajemen berpengaruh dalam meningkatkan kedisiplinan belajar siswa.

Hasil analisis menunjukkan bahwa ratarata nilai kelompok eksperimen yang mendapatkan layanan bimbingan manajemen diri memperoleh nilai tinggi, perolehan nilai yang tinggi menunjukkan adanya perubahan yang berarti terhadap kedisiplinan belajar siswa.

Selanjutnya, hasil analisis kelompok kontrol yang tidak mendapatkan layanan bimbingan manajemen diri namun hanya mendapatkan perlakuan layanan informasi dari konselor sekolah tetap berada pada kategori rendah, perolehan nilai tersebut menunjukkan tidak ada perubahan yang berarti terhadap kedisiplinan belajar siswa.

Uraian diatas, dapat menunjukkan perbedaan tingkat kedisiplinan belajar siswa antara kelompok eksperimen dan kelompok kontrol. Hal ini, dapat diartikan bahwa ada perbedaan antara siswa yang diberikan bimbingan manajemen diri dengan siwa yang diberikan layanan informasi oleh konselor sekolah. Oleh karena itu, dapat disimpulkan bahwa bimbingan manajemen berpengaruh dalam meningkatkan kedisiplinan belajar siswa kelas XI SMA Islam Athirah 1 Makassar, artinya semakin diberi layanan bimbingan manajemen diri, maka akan diikuti dengan meningkatnya kedisiplinan belajar siswa.

Hasil penelitian ini, sejalan pula dengan pendapat Corey (Prawira: 2014) yang mengemukakan bahwa terapis kognitif bertujuan untuk mengajarkan konseli bagaimana menjadi terapis bagi dirinya sendiri. Proses mengajaran meliputi menyediakan informasi bagi konseli tentang bagaimana mempresentasikan masalah mereka dan mencegah masalah itu terulang kembali. Oleh karena itu, konselor diharapkan mencari keyakinan yang dogmatis dalam diri konseli dan secara akurat mencoba menguranginya, sehingga tujuan utama dari terapi adalah meningkatkan kesadaran individu terhadap keyakinan irasional menjadi keyakinan yang lebih akurat, adaptif dan berbasis realitas.

\section{SIMPULAN DAN SARAN}

Berdasarkan hasil penelitian tentang penerapan bimbingan manajemen diri dalam meningkatkan kedisiplinan belajar siswa kelas
XI SMA Islam Athirah 1 Makassar, maka dapat dikemukakan beberapa kesimpulan sebagai berikut:

1. Proses dan hasil pelaksanaan bimbingan manajemen diri dilakukan melalui pelatihan yang terdiri dari lima (5) kali pertemuan dengan materi : a) self monitoring, b) stimulus control dan c) self reward. Hasil pelatihan diperoleh melalui observasi menunjukkan bahwa pada pertemuan pertama siswa masih ragu dalam melaksanakn pelatihan, seperti halnya juga pada pertemuan kedua. Namun pada pertemuan ketiga, keempat dan kelima antusias siswa dalam pelatihan sangat tinggi yaitu siswa mampu melaksanakan dengan baik ke tiga materi yang diberikan melalui LK (lembar kerja) yang diberikan setiap sesi pertemuan. Sedangkan hasil penguasaan materi melalui evaluasi materi yang diberikan disetiap akhir pertemuan yaitu siswa mampu memahami materi yang disajikan peneliti dan mampu mengaplikasikannya.

2. Deskripsi tingkat kedisiplinan belajar kelompok eksperimen siswa kelas XI SMA Islam Athirah 1 Makassar sebelum diberikan perlakuan bimbingan manajemen diri, dari hasil pre-test berada pada kategori rendah. Sedangkan tingkat kedisiplinan belajar siswa SMA Islam Athirah 1 Makassar setelah diberikan perlakuan manajemen diri, hasil post-test menunjukkan perubahan dari tingkat kedisiplinan belajar yang rendah menjadi tinggi.

3. Deskripsi tingkat kedisiplinan belajar kelompok kontrol siswa kelas XI SMA Islam Athirah 1 Makassar sebelum dan setelah diberikan layanan informasi cara belajar efisien dari hasil baik pre-test maupun hasil post-test tidak menunjukkan perubahan yang berarti atau tetap berada pada kategori rendah.

4. Ada perbedaan bimbingan manajemen diri dengan layanan informasi cara belajar efisien dalam meningkatkan kedisiplinan belajar siswa kelas XI SMA Islam Athirah 1 Makassar.

Adapun saran dari penelitian ini yaitu:

1. Baik kiranya konselor menerapkan bimbingan informasi manajemen diri didalam mengatasi masalah kedisiplinan belajar siswa 
2. Baik kiranya kalau disekolah itu dibentuk konselor sebaya maka mereka perlu dilatih dalam melaksanakan disiplin manajemen diri untuk membantu teman-temannya yang kurang disiplin dalam belajar.

3. Disarankan bagi peneliti lainnya untuk melakukan penelitian serupa dengan populasi dan sampel yang lebih luas

\section{DAFTAR RUJUKAN}

Undang Undang RI No. 30 Tahun 2003. Tentang Sistem Pendidikan Indonesia. Bandung: Citra Umbara

Arsanti. 2015. Pengaruh Teknik Role Playing dalam Bimbingan Kelompk terhadap Perilaku Disiplin Siswa di SMK Negeri 2 Barru. Tesis.

Bahri. 2012. Pengaruh Reinforcem ent Terhadap peningkatan kedisiplinan dan kepercayaan diri siswa SMA Negeri 1 Ujung loe Kab. Bulukumba. Tesis.

Bungin, Burhan. 2013. Metodologi Penelitian Kuntitatif: Komunikasi, Ekonomi, dan Kebijakan Publik Serta Ilmu-ilmu Sosial Lainnya. Jakarta: Kencana

Cormier, L.S. 2009. Interviewing For Helper Skil and Cognitif Behavior Intervension. Jakarta: Publishing Company.

Desmita. 2007. Psikologi Perkembangan. Bandung: Remaja Rosdakarya.

Prawira, E, A. 2014. Pengaruh Penerapan Teknik Manajemen Diri terhadap Kedisiplinan Siswa di SMK Negeri 1 Bulukumba. Tesis

Rasmidah. 2015. Pengaruh Latihan Regulasi Diri dalam Bimbingan Kelompok terhadap Kedisiplinan siswa di SMK Negeri 2 Pinrang. Tesis.

Riduwan. 2009. Belajar Mudah Penelitian Untuk Guru-Karyawan Dan Peneliti Pemula. Bandung: Alfabeta.

Sugiyono. 2011. Metode Penelitian Pendidikan (Pendekatan Kuantitatif, Kualitatif, dan $R$ dan $D)$. Bandung: Alfabeta.

Uno, H. B. 2006. Model Pembelajaran. Menciptakan Proses Belajar Mengajar yang Kreatif dan Efektif. Jakarta: Bumi Aksara. 